\title{
The endemisation of schistosomiasis in Porto de Galinhas, Pernambuco, Brazil, 10 years after the first epidemic outbreak
}

\author{
Constança Simões Barbosa ${ }^{1 /+}$, Onicio Batista Leal-Neto ${ }^{1}$, Elainne Christine Souza Gomes ${ }^{1,2}$, \\ Karina Conceição Gomes Machado de Araújo ${ }^{3}$, Ana Lucia Coutinho Domingues ${ }^{4}$
}

\begin{abstract}
${ }^{1}$ Centro de Pesquisa Aggeu Magalhães-Fiocruz, Av. Moraes Rego s/n, 50670-420 Recife, PE, Brasil ²Centro Acadêmico de Vitória, Universidade Federal de Pernambuco, Vitória de Santo Antão, PE, Brasil ${ }^{3}$ Departamento de Morfologia, Universidade Federal de Sergipe, São Cristóvão, SE, Brasil ${ }^{4}$ Departamento de Medicina Clínica, Universidade Federal de Pernambuco, Recife, PE, Brasil
\end{abstract}

In 2000, after heavy rains and floods in Porto de Galinhas, Pernambuco, Brazil, an outbreak of schistosomiasis was recorded, of which 62.2\% (412 cases) were of the acute clinical form. Between 2001-2009, occasional findings of Biomphalaria snails parasitised by Schistosoma mansoni indicated that disease transmission was still occurring. This motivated a new epidemiological survey between August-December 2010 to provide an update of the occurrence of this health hazard and to investigate the process of disease endemisation at this locality. This survey gathered parasitological, clinical and malacological data. The results of this survey, compared with data from the year 2000 survey, showed the following: (i) over these 10 years, there were declines in the total percentage of cases and the percentage of acute forms, (ii) the acute clinical form now represents $23.3 \%$ in contrast with the $62.2 \%$ detected in 2000 and (iii) the current prevalence of schistosomiasis is 15.7\%, while in $200032.1 \%$ of the individuals were diagnosed as parasitised. Today, the chronic clinical form represents $76.7 \%$ of the total number of cases diagnosed, thus showing that over the 10-year period the occurrences of clinical forms became inverted. These findings, together with visual observation of insalubrious environmental conditions, indicate that schistosomiasis has become endemic in Porto de Galinhas.

Key words: schistosomiasis - epidemiological monitoring - endemic diseases

The expansion of schistosomiasis to urban and touristic localities has been observed in several places in Brazil. This has been accompanied by human migration toward these development centres, where employment in general services for unskilled labourers is available. Underemployed individuals in these places begin living in peripheral agglomerations where municipal services are unable to provide the necessary infrastructure to accommodate the influx of new residents. Many of these migrants come from areas that are endemic for schistosomiasis and contribute towards transmission and establishment of the disease in localities that were previously free from it by introducing the parasite and creating conditions that favour establishment of habitats and foci for the vector molluscs (Kloos et al. 1980, 2010, Ximenes et al. 2000, 2003, Barbosa et al. 2004).

The frequency of reports of urban schistosomiasis cases has been increasing in Brazil, with transmission patterns observed and recorded in several localities where touristic developments have been stimulated without proper structural support and without environmental regulation and inspection. As a result, individuals without previous exposure may develop the acute form of the disease (Enk et al. 2008, 2010, Massara et al. 2008).

Financial support: CNPq, SVS/MS

+ Corresponding author: cbarbosa@cpqam.fiocruz.br

Received 27 April 2011

Accepted 26 July 2011
In the state of Pernambuco (PE), the continual expansion of schistosomiasis to touristic coastal areas is ultimately determined by the migration of workers from the zona da mata (the "forest zone", an endemic area for schistosomiasis) attracted by the chance of employment in civil construction, craftwork trading and holiday homes. These rural migrants establish themselves at the margins of beach localities by constructing peripheral spaces, where the absence of sanitary and healthcare infrastructure leads to the deposition of faecal material into the open air, posing a high risk to health. The eggs of Schistosoma mansoni, launched in breeding with the faeces, will infect the snails and in the rain season these molluscs are loaded into the backyards, infecting people who never had contact with the parasite allowing the emergence of acute human cases of illness (Barbosa et al. 2010).

The village of Porto de Galinhas, which is located in Ipojuca, $47 \mathrm{~km}$ south of the metropolitan region of Recife, $\mathrm{PE}$, is a typical representative of this occupation model. Its natural resources have been destroyed through the unscrupulous expansion of the real estate sector and through landfills in mangrove swamp areas where the marginalised population accumulates. This present-day context has its historical roots in the 1970s, a time when a crisis in the sugar cane sector led to a growth in tourism activities as a new option for the local economy; at the same time, the development of the Suape port and industrial complex led to incorporation of Ipojuca in the metropolitan region of Recife and its inclusion in national and international-scale trade routes. With the opening of good highways, people started to visit Porto de Galinhas to enjoy its landscapes of immense coconut groves, natural 
pools of warm, crystal-clear water and extensive stretches of beach. The bars and restaurants that were set up precariously and offered a low quality of services caused a portion of the native population that had lived along the seashore, supported by small-scale fishing activities, to migrate to more distant areas of the beaches, thus establishing an exclusive spatial arrangement and imposing a new form of social organisation (Barros 2002).

At the locality of Porto de Galinhas, which is considered the largest centre of tourist attraction in PE, an epidemiological survey conducted in the year 2000 recorded 412 acute cases of schistosomiasis among the 2,830 people living in the localities of Merepe III, Salinas, Pantanal, Socó and Vila de Porto. Today, this population has almost doubled, such that 5,607 people are now living in these settlements under insalubrious conditions. At these localities, delineation of the epidemiological scenario of schistosomiasis began during the heavy rains in 2000, which resulted in the flooding and overflowing of ditches. This, in turn, led to the spread of faecal material and the consequent contamination of the vector snails that were already present in these areas. The floods carried the infected molluses into the backyards of homes and invaded these homes. This exposes the population to infective larvae of vector snails and caused an epidemic outbreak of acute schistosomiasis among residents, vacationers and tourists who were in the area (Barbosa et al. 2001).

In some studies of schistosomiasis, it has become feasible to incorporate epidemiological information using tools within geographical information systems and these studies have contributed towards understanding the spatial dynamics of schistosomiasis transmission and its temporal interactions. Biological, climatic, socioenvironmental and other data can be integrated and correlated to define, explain and monitor environments in which the disease is occurring, thereby providing information to governing bodies for planning and directing healthcare actions (Bavia et al. 2001, Araujo et al. 2007, Guimaraes et al. 2008).

The aim of this study was to gather parasitological and clinical data through an epidemiological survey among the resident population in Porto de Galinhas in order to map out and assess the current expression of schistosomiasis in this locality, 10 years after the occurrence of the epidemic of 2000 .

\section{PATIENTS, MATERIALS AND METHODS}

In the present epidemiological investigation carried out in Porto de Galinhas, the same parameters for gathering parasitological, serological and clinical data in the first survey in 2000 were maintained, as described in the methods below. Both surveys were based on censuses and covered the resident populations in the settlements of Merepe III, Salinas, Pantanal, Socó and Vila de Porto, which are subject to periodic flooding during the rainy season.

The epidemiological survey was begun in August 2010 , with new mapping of the region to construct a georeferenced diagram highlighting streets, homes and the breeding sites of the vector molluscs. The georeferenced points were marked out using the Global Positioning System (GPS) in Universal Transverse Mercator projection with the SAD69 reference ellipsoid. The homes and their inhabitants were registered in order to define the physical area of the study, the number of households and the number of inhabitants. The analysis unit was the street block and the participants were all of the residents who at the time of the survey provided samples for parasitological and clinical diagnoses.

The parasitological survey was conducted between August-December 2010 by collecting faecal material from all individuals in the registered population. The parasitological faecal examination was performed using the Kato-Katz quantitative method (Katz et al. 1972) with two slides per patient.

The clinical investigation of patients presenting with schistosomiasis was conducted between September-December 2010 and the acute clinical forms were defined based on the following criteria: absence of previous treatment for schistosomiasis and absence of previous exposure, affirmation of recent contact or exposure (within the last 6 months), parasitological faecal examination showing eggs of $S$. mansoni and recent clinical signs and symptoms (fever, diarrhoea, body pains or eosinophilia greater than 1,000 eosinophils $/ \mathrm{mm}^{3}$ ).

A preliminary malacological survey was conducted during August and September 2010 to identify breeding sites for Biomphalaria. Because there are no natural freshwater accumulations in Porto de Galinhas, all of the water accumulations where live molluscs of the genus Biomphalaria were found were defined as artificial breeding sites and included vacant plots of land, flooded backyards and puddles of rainwater in the streets. Once a breeding site had been identified and georeferenced, malacological sampling was performed, consisting of gathering as many snails as possible within a 15 -min period. The species was identified using the technique of dissection of the genital apparatus (Deslandes 1951). Investigation of infection of the molluscs by $S$. mansoni was done by exposure to light in order to stimulate elimination of cercariae (Souza \& Lima 1990).

The data from the parasitological and malacological surveys (2010) were processed and organised in a Microsoft Excel 2007 spreadsheet. For Table and Figs 1, 2, data stored in a Microsoft Excel spreadsheet were used from the year-2000 survey conducted in the same locality by the same team of this present study. Statistical analysis to compare the intensities of infection [eggs per gram (epg) of faeces] in each locality between the years 2000 2010 was done using the Student's $t$ test. The data that were georeferenced using GPS were transferred to the GPS TrackMaker software; after adjusting the points and tracks, this resulted in a thematic map of each locality that identified homes, streets and breeding sites for vector molluscs. For descriptive spatial analysis on the data and construction of risk maps, the TerraView version 3.6 software was used (dpi.inpe.br/terraview/index.php). Kernel intensity estimators were used to estimate the case density per unit of area and intensity of infection due to $S$. mansoni within the epidemiological context of case occurrence. This made it possible to estimate the number of events per unit of area in each cell of a regular grid over the region studied. The kernel estimator generates surface densities in order to identify hot points formed by concentrations of events grouped around a spatial distribution, thereby expressing occurrences of risk (Bailey \& Gatrell 1995). 
TABLE

Parasitological characteristics of the cases of schistosomiasis mansoni diagnosed in Porto de Galinhas, Pernambuco, Brazil, in 2000 and 2010

\begin{tabular}{|c|c|c|c|c|c|c|}
\hline \multirow[b]{2}{*}{ Locality/years } & \multicolumn{2}{|c|}{$\begin{array}{l}\text { Number of coproscopy } \\
\text { (n) }\end{array}$} & \multicolumn{2}{|c|}{$\begin{array}{l}\text { Positive cases } \\
\text { (\%) }\end{array}$} & \multicolumn{2}{|c|}{$\begin{array}{l}\text { Eggs per gram of faeces } \\
\text { (mean) }\end{array}$} \\
\hline & 2000 & 2010 & 2000 & 2010 & 2000 & 2010 \\
\hline Merepe III & 292 & 315 & 29.4 & 4.4 & $219( \pm 462)$ & $134( \pm 268)$ \\
\hline Salinas & 771 & 1,263 & 21.9 & 20.6 & $99( \pm 151)^{a}$ & $195( \pm 436)^{a}$ \\
\hline Pantanal & 487 & 291 & 49.5 & 13.7 & $160( \pm 222)^{a}$ & $83( \pm 140)^{a}$ \\
\hline Socó & 462 & 590 & 33.9 & 16.3 & $159( \pm 274)$ & $106( \pm 198)$ \\
\hline Vila de Porto & 50 & 241 & 18 & 6.6 & $210( \pm 194)$ & $116( \pm 160)$ \\
\hline Total & 2,062 & 2,700 & 32.1 & 15.7 & $152( \pm 266)$ & $127( \pm 370)$ \\
\hline
\end{tabular}

$a: \mathrm{p}<0.05$.

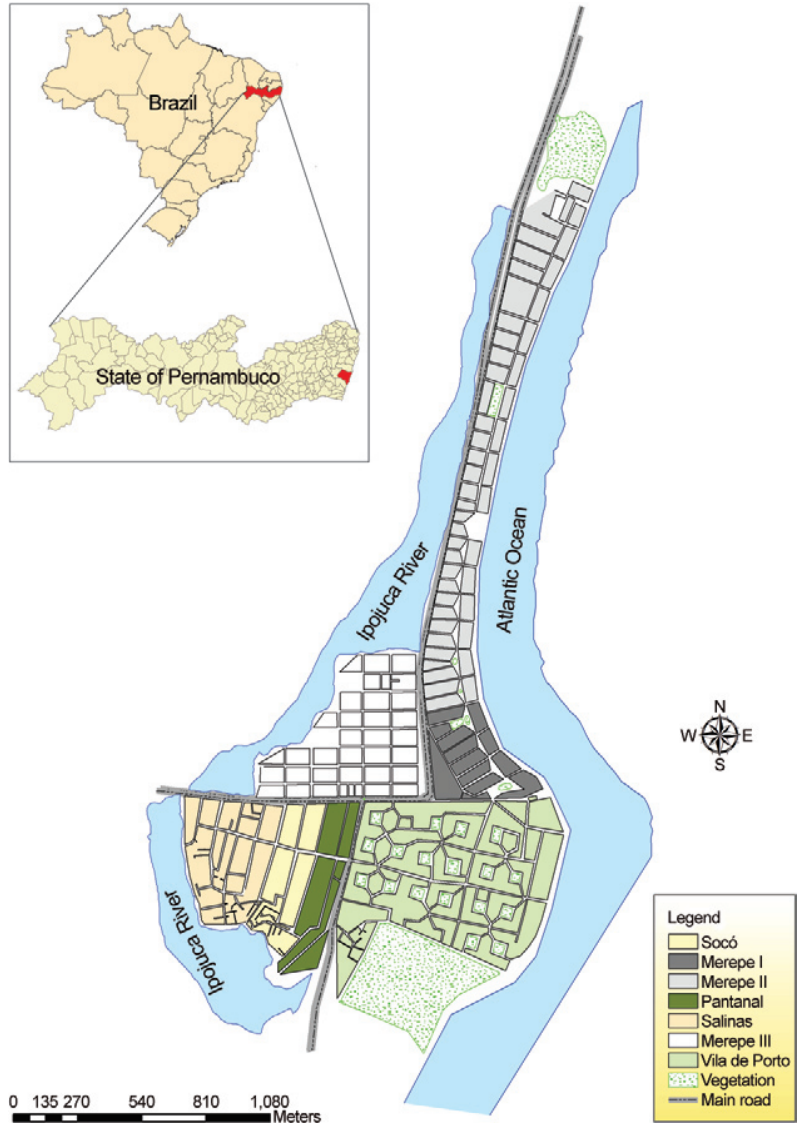

Fig. 1: localities in Porto de Galinhas, Pernambuco, Brazil, where epidemiological surveys were conducted in 2000 and 2010.

In the present study, 200-m bands were used for kernel estimators for human cases in the years 2000 and 2010.

This project was approved by the Research Ethical Committee of the Aggeu Magalhães Research CentreFiocruz (Opinion Report 14/2010).

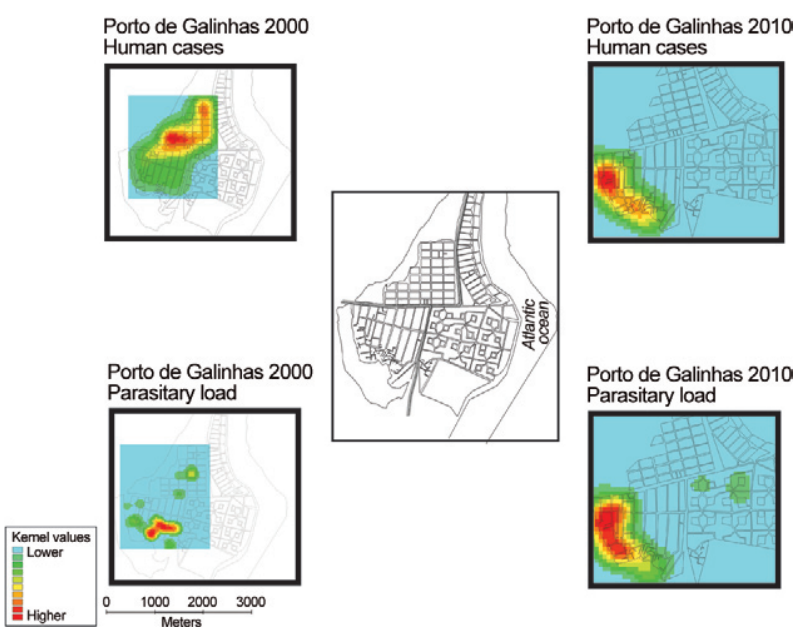

Fig. 2: Kernel maps showing the spatial distribution of cases of schistosomiasis and intensity of infection (eggs per gram of faeces) according to locality of Porto de Galinhas, Pernambuco, Brazil, in 2000 and 2010.

\section{RESULTS}

The georeferenced diagram constructed in August 2010 (Fig. 1) shows the localities in Porto de Galinhas (with their respective street blocks) where the surveys were conducted in 2000 and 2010.

Between August-December 2010, 4,300 homes with 5,607 residents were registered. The parasitological survey investigated 2,700 patients and 425 cases of schistosomiasis were diagnosed. Clinical examinations were performed on 228 patients who were positive for S. mansoni and who went to the local healthcare clinic in compliance with the appointments that were set and communicated to all diagnosed individuals. The clinical and epidemiological criteria established for case definition made it possible to select 175 patients (76.7\%) presenting the chronic clinical form of the disease. The Sali- 


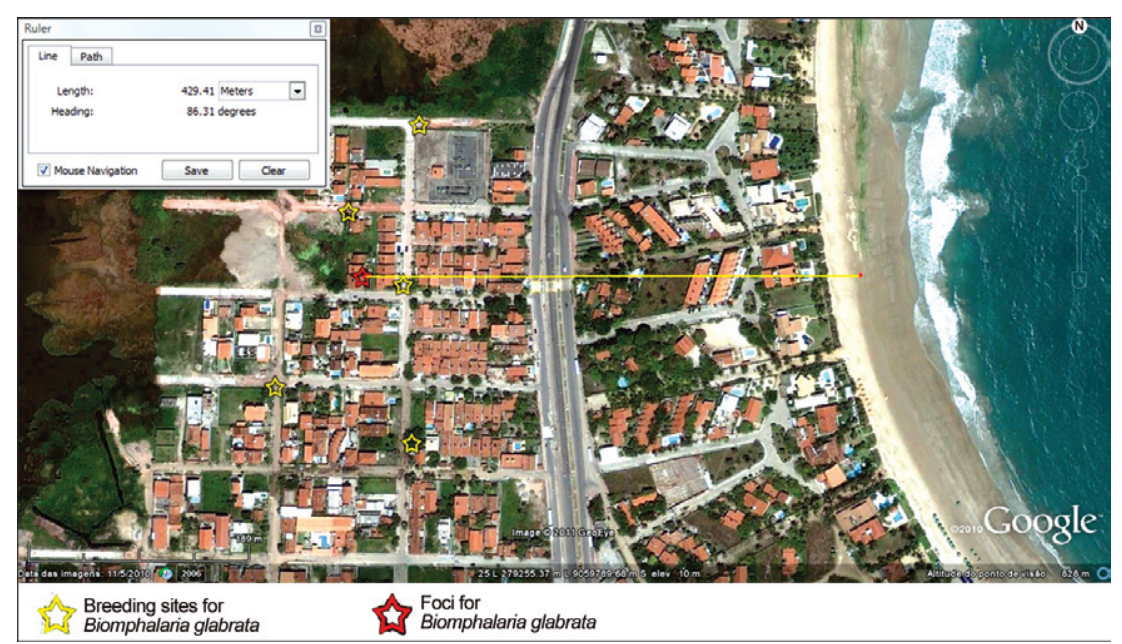

Fig. 3: spatial distance to the sea of the foci of vector molluscs for schistosomiasis identified in Merepe III, Porto de Galinhas, Pernambuco, Brazil, 2010.

nas community was most intensely parasitised, with the highest number of acute clinical cases. Table shows the percentage of positive human cases and parasitic load (epg) for S. mansoni in the two surveys (2000 and 2010) and demonstrates a statistically significant increase in the intensity of the infection (epg) in Salinas, which today has the largest number of cases of schistosomiasis.

Fig. 2 shows the spatial distribution of human schistosomiasis cases and their parasitic loads in the region of study. It can be observed that there was a displacement of the geographic occurrence of human cases of schistosomiasis, which originally were predominantly in the Merepe area, but now are concentrated in the peripheral communities of Salinas and Socó, where the highest parasite loads or highest spatial concentrations of intensity of infection are also seen (Fig. 1). All of the patients were treated with praziquantel (Fiocruz) at a dose of $50 \mathrm{mg}$ / $\mathrm{kg}$ for adults or $60 \mathrm{mg} / \mathrm{kg}$ for children less than $30 \mathrm{~kg}$ in weight or under 15 years of age.

Between August-September 2010, 36 breeding sites were identified and demarcated, from which 3,329 snails were collected and examined. The snails were found in abundance on the streets, in backyards and on flooded land, thus characterising persistence of the foci in homes and their surrounding areas. The only species found was Biomphalaria glabrata. In two of the most productive foci, this species showed infection rates of $45 \%$ and $42.2 \%$. Fig. 3 shows the focus of schistosomiasis found nearest to the sea.

\section{DISCUSSION}

The evaluation of the data resulting from the two epidemiological surveys conducted 10 years apart allows the observation that schistosomiasis is becoming endemic in Porto de Galinhas because of an accelerated process of disorderly occupation of spaces without any regulation by the municipal sectors responsible for urbanisation, the environment and the healthcare of the population living there. The present epidemiological structure, delimited by the foci of the disease, is characterised by human

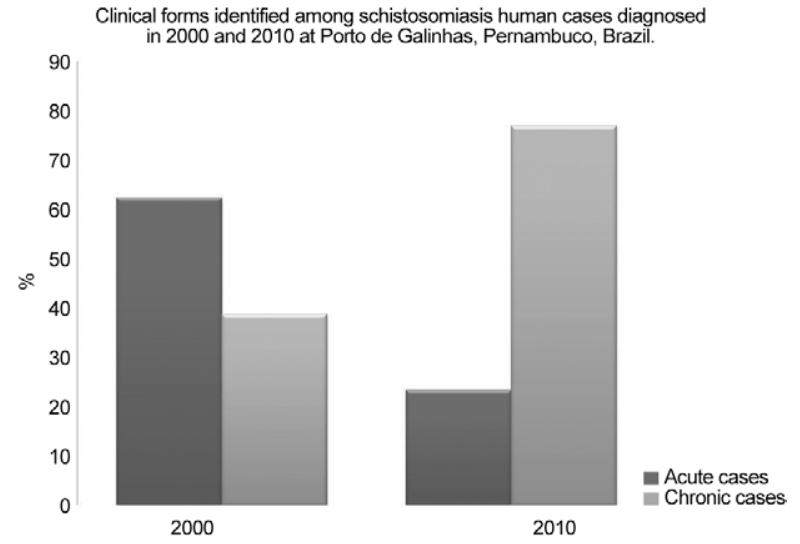

Fig. 4: the clinical forms of human cases diagnosed positive for Schistosoma mansoni in 2000 and 2010 in Porto de Galinhas, Pernambuco, Brazil.

invasion into areas that ought to be preserved. Actions by individuals or companies are promoting landfills in the remaining areas of mangrove swamps or natural sandbanks, where wooden shacks, homes made of masonry, commercial establishments or guesthouses are constructed on streets into which sewage pipes empty their contents, thereby creating conditions that favour the proliferation of vector molluscs. All of this is taking place without any attention and interference from inspection activities and is promoting the establishment of transmission foci of this endemic disease.

In the case of Porto de Galinhas, the entry of individuals infected with schistosomiasis was without doubt the necessary condition for the parasite to be introduced. However, this in itself was insufficient for the disease to become established and continue being reproduced year after year, encrusted within the environment in the form of foci of active transmission. The intensive migration of parasitised individuals originating from the zona $d a$ mata region of $\mathrm{PE}$ should have been a warning sign for 
health surveillance action in an important touristic locality that has invested in advertising to attract travellers by promising scenes of paradise. Schistosomiasis has become established there and transmission continues to be active because parasitised individuals remain untreated and not even monitored. These individuals agglomerate in peripheral spaces in a form of social organisation represented by a population of ill and underemployed people who provide services in high-value coastal locations that are occupied by tourists and vacationers.

Comparison of the data from the two surveys carried out 10 years apart in Porto de Galinhas shows that even though the number of cases positive for $S$. mansoni has fallen significantly (from 32.1-15.7\%), this environment is still producing new cases, as can be seen from the percentage of acute clinical forms diagnosed there. Moreover, the chronic cases seen there may represent cases of reinfection, given these individuals' systematic exposure to contaminated environments, considering that the majority of the patients who were diagnosed positive in 2000 were treated. Fig. 4 reinforces the epidemiological hypothesis regarding the process of endemisation of schistosomiasis in that locality, through showing the inversion in the proportions of acute and chronic cases of the disease over the period between the investigations. The geospatial shift in occurrences of cases from Merepe (2000) to Salinas and Socó (2010) can be explained in terms of the environmental improvements that were introduced in Merepe, where the streets were asphalted in 2005 , which partially impedes maintenance of temporary breeding sites. Breeding sites and foci of vector molluscs have gradually become established in the peripheral areas of Salinas, Socó and Pantanal, which have agglomerates of people living in very poor housing on stilts, flooded streets and sewage flowing out in the open air. This environment favours the seasonal transmission of disease during the rainy season. During this season, which runs from March-August, the foci expand, thus carrying the infected snails to plots of land located in the more valuable areas occupied by the middle or upper classes.

This study in Porto de Galinhas draws attention to the fact that the process of schistosomiasis transmission cannot be analysed only from the static distribution of human cases and vectors. The dynamics of the environment within which it takes place need to be known, thus highlighting the importance of the social production of the area where the transmission occurs. It is possible that situations similar to the worrisome epidemiological scenario of disease production in Porto de Galinhas may have become delineated in an equally disastrous manner in other urban and touristic regions of Brazil; if the factors determining the dynamics of disease transmission are similar, other populations are thereby exposed to the risk of becoming infected. The studies in Porto de Galinhas will be continued to determine the causal factors, with emphasis on the development dynamics of the foci of vector snails and their capacity to expand in the dry and wet seasons.

In the most important touristic locality in PE, public indifference regarding disorderly occupation of urban spaces, together with lack of assistance in providing basic environmental sanitation, has influenced and modulated the socioenvironmental structure. It has given rise to an insalubrious environment and undermined the health of both resident and transient human populations in the area. There is an urgent, immediate need for local intervention by the health surveillance officials and other sectors of the municipal authorities, in view of the existing violations. Over the short term, there is a need to prioritise public policies so that epidemiological instruments for planning, investigation and action are adopted to address the factors involved in the persistence of schistosomiasis in Porto de Galinhas.

\section{ACKNOWLEDGEMENTS}

To the technicians and students at the Schistosomiasis Laboratory and Reference Service of CPqAM/Fiocruz, for their valuable collaboration in the field and laboratory work.

\section{REFERENCES}

Araujo KC, Resendes AP, Souza-Santos R, Silveira-Junior JC, Barbosa CS 2007. Análise espacial dos focos de Biomphalaria glabrata e de casos humanos de esquistossomose mansônica em Porto de Galinhas, Pernambuco, Brasil, no ano 2000. Cad Saude Publica 23: 409-417.

Bailey TC, Gatrell A 1995. Interactive spatial data analysis, Harlow, Longman, $432 \mathrm{pp}$.

Barbosa CS, Araújo KC, Sevilha MA, Melo F, Gomes EC, SouzaSantos R 2010. Current epidemiological status of schistosomiasis in the state of Pernambuco, Brazil. Mem Inst Oswaldo Cruz 105: 549-554.

Barbosa CS, Araújo KC, Antunes L, Favre T, Pieri OS 2004. Spatial distribution of schistosomiasis foci on Itamaracá Island, Pernambuco, Brazil. Mem Inst Oswaldo Cruz 99 (Suppl. I): 79-83.

Barbosa CS, Abath F, Montenegro S, Domingues A, Spinelli V, Guida U 2001. Epidemia de esquistossomose aguda na praia de Porto de Galinhas, Pernambuco, Brasil. Cad Saude Publica 17: 725-728.

Barros JNF 2002. A dinâmica espacial e a reorganização territorial do litoral de Ipojuca: Porto de Galinhas - A emergência de um espaço turístico, MSc Thesis, Universidade Federal de Pernambuco, Recife, $189 \mathrm{pp}$

Bavia ME, Malone JB, Hale L, Dantas A, Marroni L, Reis R 2001. Use of thermal and vegetation index data from earth observing satellites to evaluate the risk of schistosomiasis in Bahia, Brazil. Acta Tropica 79: 79-85.

Deslandes N 1951. Técnica de dissecação e exame de planorbídeos. Rev Serv Espec Saude Publica 4: 371-382.

Enk MJ, Lima A, Schall V, Coelho PMZ 2008. The effect of the number of stool samples on the observed prevalence and the infection intensity with Schistosoma mansoni among a population in an area of low transmission. Acta Tropica 108: 222-228.

Enk MJ, Amaral GL, Silva MF, Silveira-Lemos D, Teixeira-Carvalho A, Martins-Filho OA, Correa-Oliveira R, Gazinnelli G, Coelho PM, Massara CL 2010. Rural tourism: a risk factor for schistosomiasis transmission in Brazil. Mem Inst Oswaldo Cruz 105: 537-540.

Guimaraes R, Freitas C, Dutra L, Moura A, Amaral R, Drummond S, Scholte R, Carvalho, O 2008. Schistosomiasis risk estimation in Minas Gerais state, Brazil, using environmental data and GIS techniques. Acta Tropica 108: 234-241.

Katz N, Chaves A, Pelegrino J 1972. A simple device for quantitative stool thick-smear technique in schistosomiasis mansoni. Rev Inst Med Trop Sao Paulo 14: 397-400.

Kloos H, Correa-Oliveira R, Reis D, Rodrigues E, Monteiro L, Gazzinelli A 2010. The role of population movement in the epidemiology 
and control of schistosomiasis in Brazil: a preliminary typology of population movement. Mem Inst Oswaldo Cruz 105: 578-586.

Kloos H, Lemma A, Kirub B, Gabre A, Mazengia B, Feleke G, De Sole G 1980. Intestinal parasitism in migrant farm labour populations in irrigation schemes in the Awash Valley, Ethiopia and in major labour source areas. Ethiop Med J 18: 53-92.

Massara CL, Amaral G, Caldeira R, Drummond S, Enk M, Carvalho O 2008. Esquistossomose em área de ecoturismo do Estado de Minas Gerais. Cad Saude Publica 24: 1709-1712.
Souza CP, Lima L 1990. Moluscos de interesse parasitológico do Brasil, Instituto de Pesquisas René Rachou/Fiocruz, Belo Horizonte, $79 \mathrm{pp}$.

Ximenes RAA, Southgate B, Smith PG, Guimarães N 2000. Migration and urban schistosomiasis. The case of São Lourenço da Mata, Northeast of Brazil. Rev Inst Med Trop Sao Paulo 42: 209-221.

Ximenes RAA, Southgate B, Smith PG, Guimarães N 2003. Socioeconomic determinants of schistosomiasis in an urban area in Northeast of Brazil. Rev Panam Salud Publica 14: 409-421. 